\title{
The Determination of Trace Levels of Cyanide by Ion Chromatography with Electrochemical Detection
}

\author{
William F. Koch \\ National Bureau of Standards, Washington, DC 20234 \\ Accepted: December 22, 1982
}

\begin{abstract}
An improved method for the determination of trace quantities of free cyanide has been developed using ion chromatography with electrochemical detection. Detection limits of $1 \mu \mathrm{g} / \mathrm{L}$ have been achieved with linearity of response over the range 1 to $1000 \mu \mathrm{g} / \mathrm{L}$. The precision of replicate injections is 0.6 percent, expressed as the relative standard deviation. The method has been applied to the analysis of dust samples.
\end{abstract}

Key words: air-particulate; cyanide; electrochemical detection; environmental monitoring; ion chromatography; trace analysis.

\section{Introduction}

The use of cyanide is widespread and vital to industries involved in such commercially important operations as electroplating, extracting precious metals, chelating metals, case hardening of steel, and fumigating orchards. The extreme toxicity of cyanide requires that its use be strictly controlled and that proper monitoring be in effect to guard against contamination.

A number of procedures for the determination of cyanide have been proposed. The classical Liebig method involves the titration of cyanide ion with silver ion in an ammoniacal solution using the formation of silver iodide as the end-point indicator [1]. ${ }^{1}$ A modification to this method uses rhodanine indicator to detect the endpoint [2]. These titration procedures generally have a minimum detection limit of 1 milligram per liter $(\mathrm{mg} / \mathrm{L})$. Interferences include sulfide and halides. Another widely used technique for the determination of cyanide is based on the colorformation of cyanogen chloride with pyridine and

About the Author: William F. Koch is a research chemist in the NBS Center for Analytical Chemistry.

\footnotetext{
${ }^{1}$ Figures in brackets indicate literature references at the end of this paper.
}

barbituric acid followed by spectrophotometric or colorimetric quantitation [2-4]. Chien discusses in detail the many factors affecting the development of color [5]. Botto has proposed an alternative colorimetric procedure using p-phenylenediamine after bromination of the cyanide [6]. These techniques have a minimum detection limit of 10 micrograms per liter $(\mu \mathrm{g} / \mathrm{L})$ with interferences from thiocyanate, cyanate, and colored or turbid solutions. Willekins and Van Den Bulcke describe a colorimetric procedure for free cyanide using lithium picrate. They report a detection limit of about $0.5 \mathrm{mg} / \mathrm{L}$ [7]. Generally the colorimetric and titration procedures require large volumes of sample (100 to $1000 \mathrm{~mL})$.

Gas chromatography has been utilized for the determination of cyanide primarily in biological samples with a minimum detection limit of $50 \mu \mathrm{g} / \mathrm{L}$ [8-12]. Several electrochemical procedures have been developed using pulse polarography [13], coulometry $[14,15]$, amperometry with flow-injection [16,17], and ion-selective electrodes [18-24]. The pulse polarographic technique is capable of distinguishing between cyanide and sulfide and has a minimum detection limit of $20 \mu \mathrm{g} / \mathrm{L}$. Coulometric procedures for cyanide have the distinct advantage of being absolute methods, requiring no calibration curves. However sulfide and oxidizable species interfere, and the minimum detection limit is estimated to be only 60 
$\mu \mathrm{g} / \mathrm{L}$. Flow-injection analysis with amperometric detection is an extremely sensitive technique with a minimum detection limit of $1 \mu \mathrm{g} / \mathrm{L}$, but once again sulfide, halides, and easily oxidized species interfere. Ion-selective electrodes (ISE) afford a rapid means of analysis with monitoring applications. Generally, the minimum detection limit for such analyses is about 20 $\mu \mathrm{g} / \mathrm{L}$, although detection limits of $2 \mu \mathrm{g} / \mathrm{L}$ [18] and 0.5 $\mu \mathrm{g} / \mathrm{L}[21]$ have been reported. Sulfide and iodide are serious interferences in these ISE procedures.

DuVal et al. have proposed an indirect ionchromatographic determination of cyanide based on the stoichiometric reactions of iodine with cyanide and subsequent quantitation of the reaction product, iodide [26]. The minimum detection limit of the procedure is reported to be $0.4 \mathrm{mg} / \mathrm{L}$. All species oxidizable by iodine are potential interferences. Bond et al. describe an ion chromatographic method for the simultaneous determination of cyanide and sulfide [26]. In this case anodic amperometric detection with mercury electrodes was used, with detection limits of about $1 \mathrm{mg} / \mathrm{L}$.

In principle, ion chromatography with electrochemical detection (IC/EC) combines the advantages of the sensitivity of flow injection analysis with the selectivity (freedom from interferences) of chromatography. Judicious choice of the electrode material and the applied voltage can further enhance the selectivity and the sensitivity. In this paper a procedure for the rapid determination of free cyanide using ion chromatography with electrochemical (amperometric) detection is described. The procedure has a minimum detection limit of about $1 \mu \mathrm{g} / \mathrm{L}$ and is relatively free from interferences such as sulfide, halides, and thiocyanate.

\section{Experimental}

\subsection{Apparatus}

A commercially available ion chromatograph (Dionex Model 10) ${ }^{2}$ with the electrochemical detector accessory (Model 35221) was used. The single-piston pump in the ion chromatograph was replaced with a dual-piston pump to reduce flow pulsations, a critical consideration in electrochemical detection. The detector system is composed of a potentiostat and a

\footnotetext{
${ }^{2}$ Certain commercial equipment, instruments, or materials are identified in this report to specify adequately the experimental procedure. Such identification does not imply recommendation or endorsement by the National Bureau of Standards, nor does it imply that the materials or equipment identified are necessarily the best available for the purpose.
}

3-electrode flow-through cell. The working electrode is a silver rod; the reference electrode is silver/silver chloride with an ion-exchange membrane junction; and the counter electrode is stainless steel. The anion exchange separator columns, type $S 2$, and the corresponding pre-column used in this work are commercially available from the Dionex Corporation. These columns have greater ion-exclusion properties than normal anion separators have. No suppressor column was necessary for this application. Chromatograms were recorded on a strip-chart recorder.

\subsection{Reagents}

All chemicals used in this work were of reagentgrade quality. The water used for dilutions was doubly distilled, deionized and passed through a $0.2 \mu \mathrm{m}$ filter.

The eluent for the ion chromatograph was prepared by mixing $10 \mathrm{~mL}$ of $0.4 \mathrm{~mol} / \mathrm{L}$ sodium carbonate, 10 $\mathrm{mL}$ of $2 \mathrm{~mol} / \mathrm{L}$ sodium hydroxide, $4 \mathrm{~mL}$ of anhydrous ethylenediamine, and $3.8 \mathrm{~g}$ of sodium tetraborate decahydrate with $4 \mathrm{~L}$ of water. A stock solution of cyanide, nominally $1000 \mathrm{ppm}$, was prepared by dissolving $1.884 \mathrm{~g}$ of sodium cyanide in $1000 \mathrm{~mL}$ of the eluent buffer solution described above. The actual concentration of cyanide in this solution was determined by a Liebig titration [1]. Calibration solutions down to $0.6 \mathrm{ppm}$ were prepared by serial dilution of this stock solution with the eluent solution. Extreme care must be exercised in preparing the low level solutions to avoid contamination. The $1000 \mathrm{ppm}$ stock solution and the bottle of sodium cyanide should be removed from the vicinity of the diluent and the low level solutions. Under no circumstances should the buffer solution used for the dilutions be exposed to an open bottle of sodium cyanide. The small amount of sodium cyanide which hydrolyzes to hydrogen cyanide is readily absorbed by the basic solution, which will subsequently bias the low level standards. There is evidence that the hydrogen cyanide will even diffuse through polyethylene bottles and bags.

\subsection{Chromatographic Procedure}

The eluent was pumped through the system at the rate of $4 \mathrm{~mL}$ per minute creating a system pressure of $2760 \mathrm{kPa}$ (400 psi). Pulsations were approximately 70 $\mathrm{kPa}(10 \mathrm{psi})$. The sample loop had a volume of 100 $\mu \mathrm{L}$. Samples and standards were loaded into the loop using a syringe and a $0.2 \mu \mathrm{m}$ syringe filter. The sample loop was rinsed with approximately $1 \mathrm{~mL}$ of the analyte solution before the sample was injected onto the column. This was done to prevent sample-to- 
sample contamination. The potentiostat controlling the 3 -electrode detection system was set at $+0.02 \mathrm{~V}$. At this potential, the system is at its maximum sensitivity for cyanide, and relatively insensitive to the halides.

The current setting of the detector was varied from $30 \mathrm{nA} / \mathrm{V}$ to $1 \mu \mathrm{A} / \mathrm{V}$ according to the cyanide concentration in the sample. Chromatograms were recorded on a strip chart recorder set at $1 \mathrm{~V}$ full scale and $0.5 \mathrm{~cm} / \mathrm{min}$. Identification was by peak retention time and quantitation was by interpolation of the calibration curve, peak height versus concentration.

\subsection{Sample Preparation}

The samples analyzed in this investigation were obtained in an industrial setting in and around an area which contained large quantities of sodium cyanide. Dust and particulate samples were collected on small (approximately $12 \times 12 \mathrm{~cm}$ ) dry laboratory tissues by repeatedly wiping over the sample area (floor, table, bench, etc.) until the majority of the dust appeared to be transferred to the tissue. The tissues were then placed in individual polyethylene bags and transported to the laboratory for analysis on the same day. The samples were transferred to individual Erlenmeyer flasks. The cyanide was extracted from the tissue with $20 \mathrm{~mL}$ of the eluent buffer solution in an ultrasonic bath at $23^{\circ} \mathrm{C}$. The extract was then loaded into the sample loop of the IC as described above. Clean tissues were run as blanks.

\section{Results and Discussion}

A chromatogram of a solution containing $0.6 \mathrm{mg} / \mathrm{L}$ cyanide is shown in figure 1 . The retention time for cyanide is $4.5 \mathrm{~min}$. Under the same conditions, sulfide elutes at 2.0 minutes with a response factor (peak height/concentration) similar to that of cyanide. Chloride elutes at $3.2 \mathrm{~min}$ with a response factor about 1000 times less than that of cyanide. Retention times for bromide, iodide, and thiocyanate exceed $10 \mathrm{~min}$ using this eluent. It can be concluded that the halides and thiocyanate pose no serious threat of interference with cyanide determinations unless in concentrations so great as to overload the capacity of the ionexchange separator columns. Sulfide should not interfere unless the sulfide to cyanide ratio is excessive. It is anticipated that at high levels of sulfide $(10 \mathrm{mg} / \mathrm{L})$, the chromatographic separation of sulfide and cyanide will afford baseline resolution. However, the silver working electrode may be adversely affected causing nonlinear response towards cyanide. Further research is required to determine at what

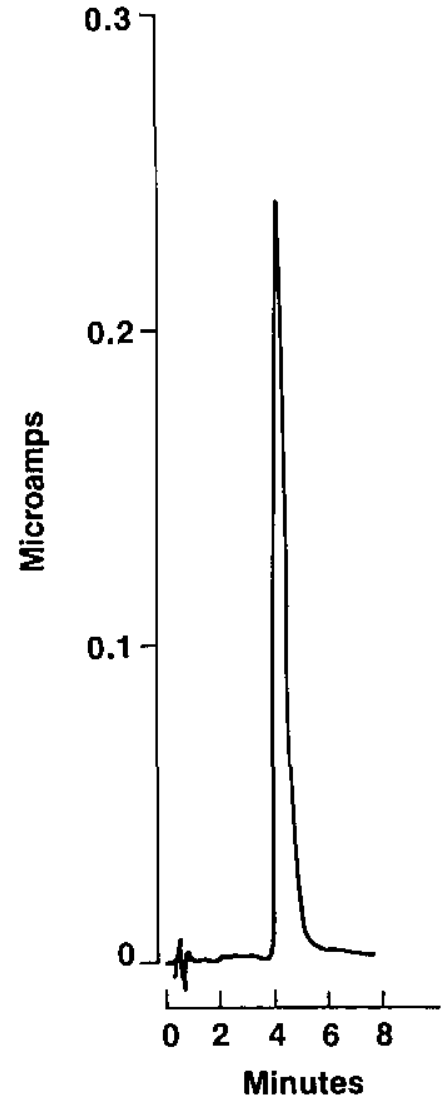

Figure 1-Chromatogram of a $0.6 \mathrm{mg} / \mathrm{L}$ cyanide solution. Electrochemical detection.

levels and to what extent sulfide poses a problem with the cyanide determination.

The linearity of response over the range 10 to 1000 $\mu \mathrm{g}$ cyanide per liter of solution is portrayed in figure 2. The detector setting was $1 \mu \mathrm{A} / \mathrm{V}$. The correlation

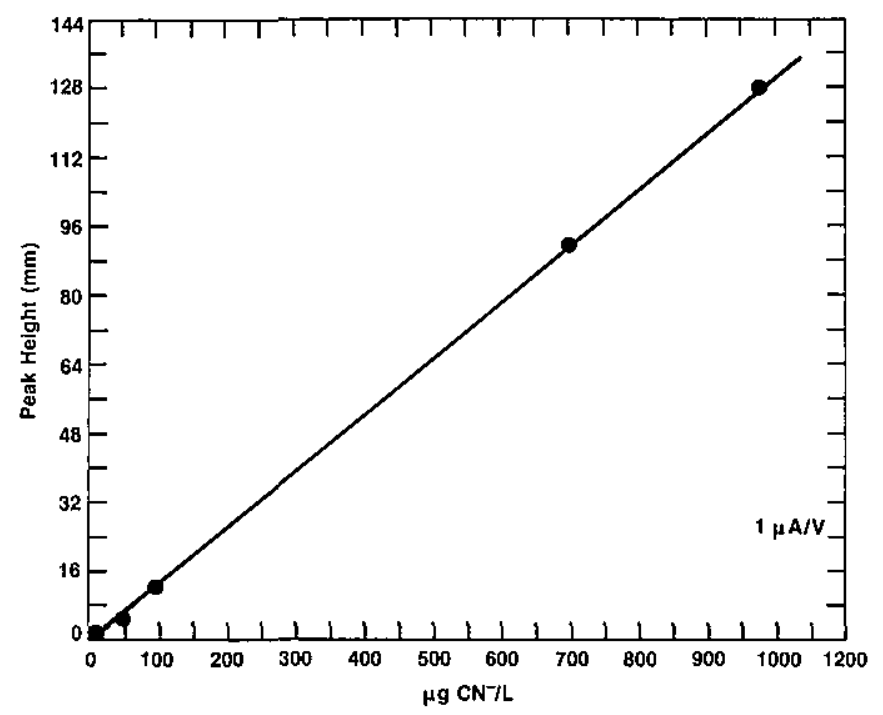

Figure 2-Calibration curve for cyanide over the range 10 to 1000 $\mu \mathrm{g} / \mathrm{L}$ using IC/EC. $1 \mu \mathrm{A} / \mathrm{V}$ setting. 
coefficient for the linear least-squares fit of the data points is 0.99997 .

For levels below $10 \mu \mathrm{g} / \mathrm{L}$, the detector sensitivity was set at $30 \mathrm{nA} / \mathrm{V}$. The response characteristics at this setting over the concentration 0.5 to $10 \mu \mathrm{g} / \mathrm{L}$ cyanide is displayed graphically in figure 3. Linearity is excellent and confirmed by a correlation coefficient

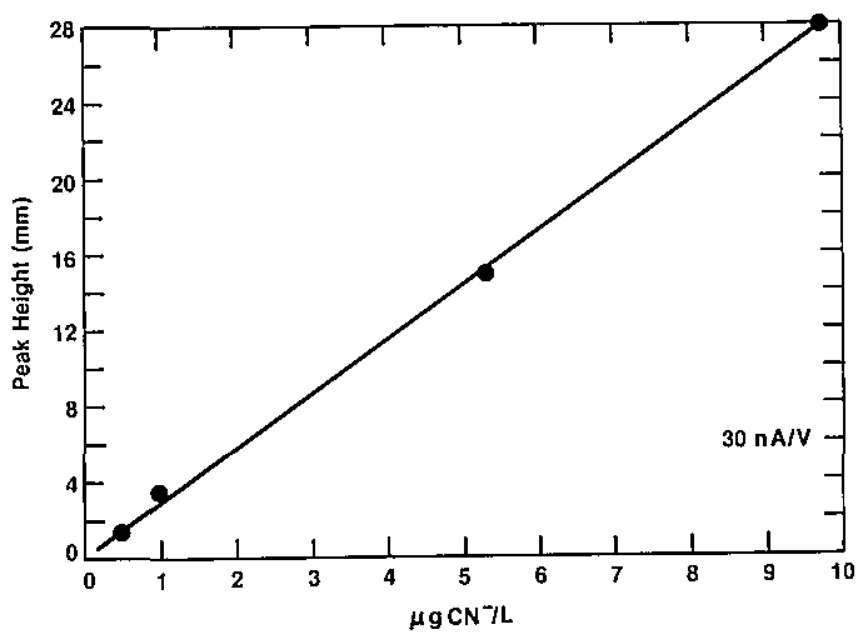

Figure 3-Calibration curve for cyanide over the range 0.5 to 10 $\mu \mathrm{g} / \mathrm{L}$ using IC/EC. $30 \mathrm{nA} / \mathrm{V}$ setting.

of 0.9997 . Detection below this level is not possible at this time due to baseline noise. At concentrations above $1000 \mu \mathrm{g} / \mathrm{L}$, the response becomes nonlinear, probably due to saturation of the electrode surface. This can be remedied by using a smaller sample loop or by diluting the sample. Replicate injections of a solution containing approximately $500 \mu \mathrm{g} / \mathrm{L}$ cyanide resulted in a precision of 0.6 percent as expressed as the relative standard deviation of five measurements. The results of the analyses of the dust samples, calculated in terms of micrograms of cyanide extracted from the tissue are shown in table 1. Only three samples contained measurable cyanide. All others are listed as less than $0.5 \mu \mathrm{g}$ which for these preliminary measurements is the overall system detection limit. Additional research is needed to improve the sampling and extracting procedures in order to reduce this limit.

Table 1. Determination of free cyanide in dust samples by IC/EC.

\begin{tabular}{llc}
\hline \hline Sample & \multicolumn{1}{c}{ Type } & $\begin{array}{c}\text { Cyanide } \\
\text { (micrograms per tissue) }\end{array}$ \\
\hline A & Floor, office & $<0.5$ \\
B & Cabinet, office & $<0.5$ \\
C & Floor, work area & 10 \\
D & Floor, work area & 130 \\
E & Table, work area & 30 \\
F & Blank & $<0.5$ \\
\hline
\end{tabular}

\section{Summary and Conclusion}

An improved method for determining trace quantities of free cyanide has been developed using ion chromatography with electrochemical detection. Detection limits of $1 \mu \mathrm{g} / \mathrm{L}$ have been achieved with linearity from this level to $1000 \mu \mathrm{g} / \mathrm{L}$. The relative standard deviation for measurements made on replicate injections is better than 1 percent. The method has been applied to the analysis of dust samples. Future research will include the investigation of the effects of large quantities of sulfide on the cyanide response, and the application of the method to air-particulate samples collected on filters and to air samples collected by impingers. In addition, the determination of total cyanide by this method will be undertaken with appropriate modifications to the standard reflux-distillation procedures [2].

The author wishes to express his gratitude to Barry I. Diamondstone of the National Bureau of Standards for his assistance in this project and to Karen Haak of the Dionex Corporation for helpful suggestions.

\section{References}

[1] Diehl, Harvey. Quantitative Analysis, Elementary Principles and Practice, Ames, Iowa: Oakland Street Science Press; 1970. 278-279.

[2] Standard Test Methods for Cyanides in Water, ASTM designation D2036.75, Annual Book of ASTM Standards, Part 31; 1980. 697-7II.

[3] Taras, M. J. Water Analysis, Chapter 48 in Standard Methods of Chemical Analysis, Sixth Edition, Vol. 2, Part B., F. J. Welcher, ed., Princeton, NJ: D. Van Nostrand Co.; 1963. 2427-2430.

[4] Broderius, Steven J. Determination of hydrocyanic acid and free cyanide in aqueous solution, Anal. Chem. 53(9): 1472-1477; 1981 August.

[5] Chien, Chun-Ching; Chang, Fu-Chung; We, Shaw-Chii. Study of colour-developing factors in spectrophotometric determination of cyanide by the pyridine-barbituric acid method, Mickrochimica Acta 1980 (II): 9-16; 1980.

[6] Botto, R. I.; Karchmer, J. J.; Eastwood, M. W. Spectrophotometric determination of uncomplexed cyanide and thiocyanate in wastewater with $\mathrm{p}$-phenylenediamine, Anal. Chem. 53(14): 2375-2376; 1981 December.

[7] Willekens, G. J.; Van Den Bulcke, A. Spectrophotometric determination of trace amounts of free cyanide in prussian blue, Analyst 104: 525-530; 1979 June.

[8] Funazo, K.; Kusano, K.; Tanaka, M.; Shono, T. Determination of cyanide ion by derivatization-gas chromatography, Anal. Lett. 13(A9): 751-757; 1980.

[9] Darr, R. W.; Capson, T. L.; Hileman, F. D. Determination of hydrogen cyanide in blood using gas chromatography with 
alkali thermionic detection, Anal. Chem. 52(8): 1379-1381; 1980 July.

[10] Funazo, K.; Tanaka, M.; Shono, T. Determination of cyanide or thiocyanate at trace levels by derivatization and gas chromatography with flame thermionic detection, Anal. Chem. 53(9): 1377-1380; 1981 August.

[11] Ditzler, M. A.; Koehan, F. L. Determination of cyanide ion by homogeneous catalysis and gas chromatography, Anal. Chim. Acta 135: 69-75; 1982.

[12] Faigle, W.; Klockow, D. Gas-chromatographische Bestimmung von Spuren an Chlorid, Bromid, Iodid, Cyanid, Thiocyanat und Nitrat in wässrigen Lösungen nach Derivatisierung mit Hilfe der Phasentransferkatalyse, Frezenius Z. Anal. Chem. 310: 33-38; 1982.

[13] Leung, L. K.; Bartak, D. E. Normal pulse polarographic quantification of cyanide and sulfide by the anodization of mercury, Anal. Chim. Acta 131: 167-174; 1981.

[14] Gibbs, R. A.; Palma Sr., R. J. Coulometric titration of free cyanide with electrogenerated hypobromite, Anal. Lett. 7(3): 167-172; 1974.

[15] Rohm, T. J.; Davidson, R. Coulometric determination of total cyanide in effluent and wastewater, Anal. Lett. A11(12): 1023-1037; 1978.

[16] Toth, K.; Nagy, G.; Feher, Zs.; Pungor, E. Novel electroanalytical techniques for pollution analysis, Z. Anal. Chem. 282: 379-387; 1976.

[17] Pihlar, B.; Kosta, L. Determination of cyanides by continuous distillation and flow analysis with cylindrical amperometric electrodes, Anal. Chim. Acta 114: 275-281; 1980.
[18] Sekerka, I.; Lechner, J. F. Potentiometric determination of low levels of simple and total cyanides, Water Research 10: 479-483; 1976.

[19] Harzdorf, C. silver/silver iodide electrodes of the second kind as sensors for cyanide, Anal. Chim. Acta 86: 103-108; 1976.

[20] Cusbert, P. J. The determination of cyanides in steelworks effluents with a cyanide-selective electrode, Anal. Chim. Acta 87: 429-435; 1976.

[21] Durst, R. A. Continuous determination of free cyanide by means of membrane diffusion of gaseous $\mathrm{HCN}$ and an electrode indicator technique, Anal. Lett. 10(12): 961-978; 1977.

[22] Sekerka, I.; Lechner, J. F. A new zero-current chronopotentiometric technique with ion-selective electrodes, Anal. Chim. Acta 93: 129-137; 1977.

[23] Gratzl, A.; Rakias, F.; Horvai, G.; Toth, K.; Pungor, E. Effect of $\mathrm{pH}$ on the response of a cyanide ion-selective electrode, Anal. Chim. Acta 102: 85-90; 1978.

[24] Bernal, J. L.; Pardo, R.; Rodriquez, J. M. Determination of cyanide in the presence of mercaptans with a selective electrode, Anal. Chim. Acta 120: 367-370; 1980.

[25] DuVal, D. L.; Fritz, J. S.; Gjerde, D. J. Indirect determination of cyanide by single-column ion chromatography, Arual. Chem. 54(4): \$30-832; 1982 April.

[26] Bond, A. M.; Heritage, I. D.; Wallace, G. G. Simultaneous determination of free sulfide and cyanide by ion chromatography with electrochemical detection, Anal. Chem. 54(3): 582-585; 1982 March. 